\section{Effect of Adrenaline Solutions on Oat Roots}

A solution of adrenaline, which is a catechol derivative, oxidizes in the presence of air and much more readily when some phenolases ${ }^{1}$ are present. Solutions of adrenaline in tap water can inhibit the growth of oat roots in the concentrations indicated below.

$\begin{array}{lcccc}\begin{array}{c}\text { Concentration of } \\ \text { adrenaline }\end{array} & 0.001 M & 0.0005 M & 0.0001 M & 0.00005 M \\ \begin{array}{c}\text { Per cent growth } \\ \text { value }\end{array} & 59.4 & 75.8 & 83.8 & 97.3\end{array}$

In addition to the effect on growth as measured by extension of roots, certain effects on cell development are of note. After forty-eight hours growth in the more concentrated solutions, it was observed that the root cap, when viewed by reflected light, was jet black and by transmitted light dark brown in colour. Under the microscope the youngest part of the root was still light, and the crest of dark root-cap cells was an excellent demonstration of this tissue.

At the root base and extending down to the region of cell expansion, the piliferous layer was seen to be stained dark brown and the root hairs remained small or undeveloped. In addition, the normal expansion of the piliferous layer had been prevented so that splitting of this tissue had occurred exposing the relatively unstained underlying tissues.

It was observed that the cell walls of the piliferous layer were stained and often the outer wall of the exodermis, this latter tissue apparently performing its classical role as a selective barrier to substances in solution. The staining was almost certainly due to the more complete oxidation of the adrenaline by a phenolase from the root cells. Tests for oxidase in normal 48 hours old roots showed that with Nadi reagent a deep blue colour developed rapidly in the root cap and root hairs and in the root generally. In the presence of peroxide the catalase of the root caused a rapid evolution of oxygen.

R. Forbes Jones.

H. G. BAKER.

Department of Plant Physiology,

Hosa Research Laboratories,

Sunbury-on-Thames.

March 6.

${ }^{1}$ Martin, G. J., Ichniowski, C. T., Wisansky, W. A., and Ansbacher, S., Amer. 'I. Physiol., 136, 66 (1942).

\section{Control of the Potato-Root Eelworm Heterodera rostochiensis Wollenweber, by Allyl Isothiocyanate}

MorgaN ${ }^{1}$ was the first to report that few eelworm cysts are found on the roots of potato plants grown together with white mustard in pots of soil infested with the potato-root eelworm. Afterwards ${ }^{2}$ it was shown that root excretions from potato plants mixed with those from white mustard seedlings will no longer stimulate the emergence of eelworm larvæ from the cysts ; this effect is also produced by black mustard, perhaps by cress, and, by certain solutions of allyl isothiocyanate, the mustard oil of black mustard seed ${ }^{3}$. Field trials with white mustard as green manure were a failure ${ }^{4,5}$, due, it has been suggested 6 , to the difficulty of applying the excretions in sufficient quantity in the field; the results with allyl isothiocyanate suggested that these difficulties might be overcome, and a small-scale field trial during 1944 gave promising results.

The mustard oil, on granular peat, was applied to the potato drills at the time of planting. Treated plants were superior to the various types of control throughout the season, and the difference became more pronounced as the season advanced. Yields were about 100 per cent above controls and the differences were statistically significant.

This is not the first occasion on which isothiocyanates have been used in combating eelworm. Smedley ${ }^{7}$ found the phenyl form to be very toxic to the eggs in the cysts, and used it in an extensive field trial; apparently unaware of the early work with white mustard and of the possible connexion of isothiocyanates with the response of larvæ to potato root excretions, the oil, adsorbed on to talc, was applied all over the treated plots some time before planting. Comparison of the results of my experiment with 160 plants with those from an extensive field trial is somewhat presumptuous ; but the results are very different. Application of phenyl isothio. cyanate at the rate of $2 \mathrm{cwt}$. per acre increased the yield by 35 per cent; smaller dressings were ineffective. On the other hand, allyl isothiocyanate at the rate of only $0 \cdot 1 \mathrm{cwt}$. or about $11 \mathrm{lb}$. per acre, increased the yield by 100 per cent; and this isothiocyanate is also far cheaper. It remains to be seen whether the greater effect of the latter is due to the method of application, which takes account of the 'interaction' between mustard oil and potato root excretion, or whether it is due to differences in the properties of the substances.

A detailed account of this work will be published elsewhere.

Department of Zoology, King's College,

Nəwcastle-upon-Tyne.

${ }^{1}$ Morgan, D. O., J. Helminth., 3," 185 (1925).

2 Trifftt, M. J., J. Helminth., 8, 19 (1930).

3 Ellenby, C., Ann. Appl. Biol., in the press.

'O'Brien, D. G., and Prentice, E. G., Scot. J. Agric., 13, 415 (1930),

${ }^{\circ}$ O'Brien, D. G., Bull. W. Scot. Agric. Coll., No. 2 (1931).

' 'McM'. Imp. Bur. Agric. Parasitol. Notes and Mem., No. 6 (1932).

${ }^{7}$ Smedley, E. M., J. Helminth., 17, 31 (1939).

\section{Use of Calomel on Onions}

THE observations of Dr. J. R. Booer on the control of onion white rot (Sclerotium cepivorum Berk) ${ }^{1}$ are very interesting. A fairly extensive experience in the use of mercurous chloride for onion seed treatment under field conditions has led me to believe that the use of this substance may have a wider significance than is realized.

A particular case may be noted. During 1942, 1943 and 1944, I had under observation plots of onion plants grown from seed which had received calomel treatment at the rate of $\frac{8}{4} \mathrm{lb}$. per $\mathrm{lb}$. of seed. In these plots I was surprised to see what appeared to be a marked degree of control of eelworm (Anguillulina dipsaci Kühn), and a marked improve. ment in the crop itself.

Laboratory tests using calomel in water are entirely negative so far as any lethal effect on eelworm is concerned, but Dr. Booer tells me that in his opinion some lethal effect is not impossible when calomel is decomposed in the soil. If this is so, and further investigation confirms that some degree of 